KASIAN Tetiana,

Ph.D in Pedagogy, Associate Professor, Honored Artist of Ukraine, Chair of Fine and Applied Arts Department, Bohdan Khmelnytsky National University at Cherkasy

e-mail: tat.kasyan@gmail.com

\title{
EDUCATIONAL INSTITUTIONS WITH DECORATIVE-AND-APPLIED DIRECTION FOR FEMALE POPULATION IN THE EDUCATIONAL STRUCTURE OF KATERYNOSLAV REGION IN THE SECOND HALF OF 19TH - EARLY 20TH CENTURY
}

\begin{abstract}
Introduction. The article deals with the problem of art education with a decorative-applied focus of the female part of the population of the Yekaterinoslav province in the second half of XIX-early XX century.

Purppose. Analyze the path of origin, development and formation of the female part of the population with a decorative and applied focus.

Methods. General scientific - historical and pedagogical analysis, synthesis, study of normative and legal documents, archival materials, scientific literature for revealing the level of scientific development of the problem of research, description of approaches and positions of scientists to its studying, studying the materials of reforms in the education of Ukraine in the second half of XIX - early XX century;

Historical and pedagogical - historical and observational, chronologically problematic, statistical analysis of scientific works, documents that allow to characterize the formation and development of arts and crafts in Katerinoslav region in the second half of XIX - early XX; systematic analysis of historical facts, archival data, scientific and methodical literature, periodicals of the mentioned period for the study and generalization of the experience of organizing the study of arts and crafts in Katerinoslav region in the second half of XIX - early XX century; generalization and systematization of the studied documents, materials and facts.

Results. The study was conducted, the main trends in the development of education with a decorative and applied direction among the population of women in Yekaterinoslav in the second half of the XIX - early XX century were revealed.

Originality. On the basis of the analysis of archival materials, documentary sources and scientific literature,
\end{abstract}

the genesis of the formation and organization of teaching arts and crafts in the Katerinoslav region of the female part of the population in the second half of XIX - early XX century was thoroughly characterized; Little known archive data (materials, facts, documents, and unknown and little-known archival documents introduced into the scientific circulation), which expand the scientific understanding of the formation and development of teaching the arts and crafts of women's cleansing of the population in the Katerinoslav region of the designated period.

Conclusion. From the foregoing it can be summa rized that due to the formation of the public education and the introduction of the elements of decorative and applied art as the basis for the artistic and aesthetic development of schoolchildren, the first stage of the wide development and development of decorative and applied art in Katerinoslav region began in the second half of XIX - early XX century.

Thus, in the ambiguous, contradictory historical part of the time, when the new was born from the old one, when it was newly tested by practice, the time was tested - a gradual process proceeded from the beginnings to the development and formation of educational institutions of various complications of the decorative and applied direction. Even then, many artistic laws were laid down, which underlie the modern practice of decorative arts and crafts.

Keywords: educational institutions for the female part of the population; arts and crafts orientation in education; Ekaterinoslav region.

Одержано редакиією 24.09.2018 Прийнято до публікаиї 29.09.2018

DOI $10.31651 / 2524-2660-2018-17-43-48$

ORCID 0000-0002-1029-7843

\section{АИСЕНКО ОАександра Микомаївна,}

кандидат філологічних наук, доцент кафедри теорії та методики дошкільної і спеціальної освіти педагогічного факультету,

Прикарпатський національний університет імені Василя Стефаника e-mail: lysenkowa@gmail.com

\section{УДК 373.5}

\section{ПСИХОАОГО-ПЕДАГОГІЧНИЙ ЗМІСТ ЦІННІСНИХ ОРІЄНТАЦІЙ СУЧАСНОГО ПЕДАГОГА ДОШКІАЬНОї ОСВІТИ}

У статті здійснено аналіз иіннісних орієнтаиій особистості у психологічній літературі. Наголошено, шо найбільшого значення поняття иіннісних орієнтаиій отримали лише у гуманістичній $і$ екзистениіальній психології. Акиентовано увагу на тому, шо джерелом иінностей особистості є мораль суспільства. Доведено, шо основною передумовою психологічної готовності студента до педагогічної діяльності у системі дошкільної освіти $є$ формування $i$ розвиток у нъого иіннісних орієнтаиій.
Ключові слова: иінність; иіннісні орієнтаиії особистості; дошкільний заклад; майбутній педагог закладу дошкільної освіти.

Загамьна постановка проблеми: У сучасній ситуації переосмислення орієнтирів побудови професійної кар'єри, в умовах переорієнтації навчальновиховного процесу ЗВО України, особливо гостро постає проблема розвитку ціннісних та значущих проявів особистості, 
які могічно відображаються у ціннісних орієнтаціях майбутнього педагога.

Мета роботи: проаналізувати та всебічно розкрити поняття ціннісних орієнтацій педагога, з'ясувати особливості процесу підготовки фахівців дошкіцьного виховання.

Виклад основного матеріалу: Особливого значення у контексті поставленої нами проблеми набувають дослідження, пов'язані 3 аксіологічного підготовкою педагога дошкільної освіти, оскільки його робота відрізняється специфікою контактування 3 віковими особливостями дітей. Як відомо, дошкільний вік характеризується підвищеною сприйнятливістю до соціальних впливів. Дитина, прийшовши в цей світ, вбирає в себе все мюдське: стилі спілкування, поведінки, ставлення. Тому роль педагога як "соціального провідника" дуже велика i відповідальна, адже він стає точкою відиіку у навчанні, вихованні та розвитку особистості дошкільника (Ш. Амонашвілі, Р. Буре, С. Козцова, Т. Куликова, О. Макаренко, В. Сухомлинський, С. Русова та ін.).

Вирішення даної проблеми найбільш ефективно реалізується на етапі вищої професійної освіти, у період якого відбувається змістовне наповнення ціннісних орієнтацій педагога. Важливо, щоб вихователь мав не тільки певний кругозір в галузі культури, а й досвід мотиваційного забезпечення вибору особистісних і професійних цінностей, ціннісних орієнтацій упродовж всього свого життя. Адже вихователь - це не тільки професія, суть якої транслювати знання, а й висока місія формування особистості дитини в дошкільному віці. Аише у тому випадку, коли педагог пропустить цінності через себе, він зможе сформувати ї у дітей, розвинути стійкий інтерес до царини духовної культури, виховати моральні якості, особистісну надійність і потребу у творчій діяльності.

Водночас, проблема розвитку ціннісних орієнтацій педагога - дошкільника на етапі навчання у ЗВО не отримала повного відображення в теорії $\mathrm{i}$ практиці сучасної освіти.

Совість здобувається за допомогою батьківських покарань. Вона вбирає здатність до критичної самооцінки, моральні заборони і виникнення почуття провини, коли ми не робимо того, що повинні робити. Еgо-ідеал формується в дитинстві на основі того, що батьки схвалюють або високо цінують, він спонукає $ю$ юину встановлювати дмя себе високі стандарти поведінки і мислення, в результаті яких з'являється почуття гордості і самоповаги.

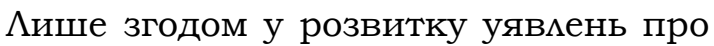
особистість в зарубіжних теоріях неофрейдизму виявляється певна загальна закономірність, яка полягає в поступовому прийнятті ідеї про соціальну

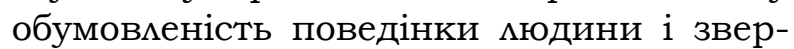
ненні до проблеми ціннісних орієнтацій (С. Рубінштейн [1], Е. Фромм [2], та ін.).

Однак найбільшого значення поняття ціннісних орієнтацій отримали мише у гуманістичній і екзистенціальній психології.

Центральною проблемою гуманістичного спрямування є проблема регулятивної ролі вищих мюдських цінностей, зокрема А. Маслоу [3], який займався проблемою мотивації, вказує на певні цінності, які притаманні кожній мюдині. Він виділяє дві групи цінностей: цінності буття (це вищі цінності, притаманні свідомим Аюдям, такі як добро, істина, справедливість, краса) і дефіцітарні цінності (це нижчі цінності, оскільки вони орієнтовані на задоволення певної нагальної потреби).

Відповідно до теорії С.Рубінштейна, основний мотив поведінки - це прагнення до самоактуалізації, що $€$ найваж-

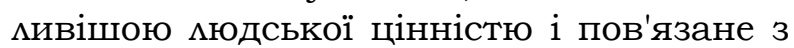
умінням зрозуміти себе, свою внутрішню природу і навчитися "співналаштовуватись" відповідно до цього з природою, будувати свою поведінку, виходячи з неї. Це не одномоментний акт, а процес, який не має кінця, це спосіб проживання, роботи та взаємовідносин зі світом, а не одиничне досягнення [1].

Д. Узнадзе вважав, що джерелом цінностей особистості $€$ мораль суспільства. Він виділяє також ряд ціннісних орієнтацій, які не продиктовані моральними нормами, наприклад, допитливість, ерудиція, спілкування і т.д. Моральні норми і цінності формуються і підтримуються за допомогою зовнішнього підкріплення. Вони виступають скоріше як засоби, умови досягнення внутрішніх цінностей, що є цілями особистості. Пе- 
ретворення засобів у цілі, перетворення зовнішніх цінностей в цінності внутрішні учений називає "функціональною автономією", що розуміється ним як процес трансформації "категорій знань" в "категорії значущості». "Категорії значущості" виникають у процесі самостійного усвідомлення сенсу отриманих ззовні "категорій знань" [4].

Концепція особистості Е. Фромма, що сформувалася в рамках екзистенційної психологічної школи, за багатьма своїми положеннями близька до гуманістичної психології. Осмисленість цінностей, надає їм об'єктивного, універсального характеру. Він розумів під цінностями особистості так звані "універсалії сенсу", тобто смисли, притаманні більшості членів суспільства. Суб'єктивна значущість цінності, повинна супроводжуватися прийняттям відповідальності за іï реалізацію [5]. Першу групу скмадають цінності творчості - найбільш природні і важливі. Основним шляхом їх реалізації є праця. Сенс праці полягає у тому, що Аюдина втілює у своїй професійній діяльності як особистість. Друга група - це цінності переживання. На думку дослідника, багатим ціннісним потенціалом володіє єдиним способом зрозуміти іншу Аюдину ..." [2].

У "віялі" педагогічних професій гідне місце займає вихователь дошкільного закладу. Сьогодні немає жодної країни у світі, де б не усвідомлювалося особливе значення періоду перших років життя дитини для особистісного становцення у подальші роки. Завдання розвитку сучасної дошкільної освіти входять до програми соціальної політики багатьох держав.

3 огляду на зростаючі вимоги щодо освітніх функцій дошкільного закладу, новітнього вихователя все частіше називають педагогом.

Педагог, де б він не працював - у дошкільному закладі, дитячому будинку чи інтернаті, приватному закладі чи спеціалізованій школі $є$ однією із найбільш соціально значущих мюдинознавчих професій. Його діяльність спрямована на розвиток і формування дитини. Духовне відтворення мюдини, формування особистості - таке призначення педагога у суспільстві.
У цьому полягає його найважливіша соціальна функція.

Основною передумовою психологічної готовності студента до педагогічної діяльності у системі дошкільної освіти $\epsilon$ формування і розвиток у нього ціннісних орієнтацій. Духовний світ педагога, його цінності, інтереси і мотиви - це та першооснова, яка упродовж всього його життя визначатиме особистісний розвиток, раціональне осмислення навкомишньої дійсності, професійну спрямованість, керуватиме кожною дією: у зв'язку 3 цим надзвичайно важливим стає вивчення питань педагогічної аксіології і розвиток професійноціннісної свідомості педагога дошкільної освіти.

У сучасній педагогіці аксіологія виступає іiі методологічнаою базою, яка визначає систему педагогічних поглядів, в основі яких межить розуміння і ствердження цінності $ю$ юського життя, виховання і навчання, педагогічної діяльності і освіти.

У наукових дослідженнях останніх десятиліть осмислено природу і сутність цінностей у контексті філософського, психологічного і педагогічного підходів;на їхній основі нами виокремлено притаманні для них аксіологічні аспекти: аксіогенез особистості та механізми формування i розвитку іiі ціннісних орієнтацій (З. Карпенко, Д. Аеонтьєв, Г. ОАпорт, Г. Радчук та ін.); питання цінностей освіти (I. Бех, І.Зязюн, В.Кремінь, О. Сухомлинська та ін.), педагогічних цінностей, ї змісту та класифікації (С. Вершловський, В. Кузнєцова, О. Савченко, В. Сластьонін та ін.), механізми сприяння професійноособистісній самореалізації та розвитку особистості в її професійному становленні (О. Бондарчук, В. Гриньова, Е. Зеєр, $\Lambda$. Карамушка, О. Кочарян, П. Аушин, С. Максименко, М. Марусинець, Ю. Швалб, Т. Яценко та ін.); професійноціннісні орієнтації майбутнього педагога (Н. Асташова, С.Камінська, О. Коростельова, З. Курлянд, Г. Аисенко, О. Мартинюк, Н. Нікітіна, В. Семиченко С. Хмара, М. Чаїнська та ін.), психокорекція особистісних якостей (О. Солодухова та ін.); методи діагностики ціннісних орієнтацій особистості ( $\Lambda$. Бурлачук, $\Lambda$. Смирнов, А. Серий та ін.); ціннісні орієнтації студентів
(Н. Антонова,
Н. Максимчук, 
О. Научитель, $\Lambda$. Романюк, М. Шевчук та ін); реалізація гуманістично-ціннісного підходу та ін. (О. Бондарчук, Н. Клокар, Н. Протасова та ін.); психологічна «перебудова установок" педагогічних фахівців у системі підвищення кваліфікації та ін.

Предметом педагогічної аксіології $\epsilon$ формування ціннісної свідомості, ціннісного ставлення і ціннісної поведінки особистості. Категоріальний апарат цієї науки вкАючає в себе поняття цінності, аксіологічну характеристику особистості (суб'єкта ціннісних відносин), а також загальні аксіологічні категорії (значення, сенс, благо, оцінка, потреба, мотивація, ціннісні орієнтації і відносини та ін.).

Поняття "цінність" широко використовується у філософських, етичних, психологічних і педагогічних публікаціях, активно вживається в науковопопулярній і публіцистичній мітературі. Однак автори вкладають у нього різний зміст, що природно призводить до термінологічної невизначеності. 3 огляду на цей факт, зупинимося, на більш детальному розгляді поняття "цінність".

Дана категорія може застосовуватись до- світу мюдини і суспільства. Поза: Аюдини і без мюдини це поняттяіснувати не може, оскільки цінності- не первинні, а продукуються у процесі взаємодії світу і мюдини. Водночас до цінностей відносяться тільки - позитивно значущі події і явища, пов'язані 3 соціальним процесом.

У психомого-педагогічних дослідженнях використовуються як поняття цінності, так і поняття ціннісних орієнтацій. Однозначного розрізнення цих понять у мітературі не простежується. Часто вони вживаються як рівнозначні. При вивченні характеристик суспільства, культури і окремих соціальних груп використовується термін "цінність». При вивченні окремих індивідів вживані як поняття ціннісна орієнтація так i поняття цінність. Під ціннісними орієнтаціями ми будемо розуміти відображення в

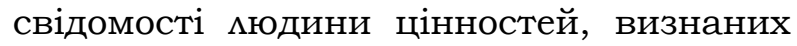
нею стратегічними життєвими цілями i загальними світоглядними орієнтирами. Ціннісні орієнтації - це інтеріоризовані особистістю цінності соціальних груп. Таким чином, цілком виправданим вважаємо модоцільність говорити про цінності особистості як іï ціннісні орієнтації.
У зарубіжній психології ціннісні орієнтації визначаються, як правило, через відносини, відображення, установки (А. Здравомислов [5], Д. Узнадзе [4], В. Ядов [6]). Причому, будучи однією 3 базових особистісних потреб, ціннісні орієнтації сягають всередину більш широкого синтетичного поняття спрямованості особистості, яка містить в собі домінуючі цінності і установки, які проявляються в будь-якій ситуації. Оскільки ціннісні орієнтації в певному сенсі перетинаються 3 поняттям спрямованості, зупинимося коротко на характеристиці останньої.

Психологічний механізм інтеріоризації дозволяє зрозуміти динаміку мотивів $\mathrm{i}$ духовних потреб мюдини. Діяльність, що здійснюється особою за певних умов, створює нові об'єкти, які викликають нову потребу. Якщо в навчальну діяльність ввести фактори, які стимулюють самодіяльність студента, то він буде перебувати в умовах розширеного формування і розвитку мотивів і духовних потреб. Студент, внутрішньо зіставцяючи свої дії і вчинки 3 майбутньою діяльністю, прогнозує іiі відповідно до соціальних вимог і трансформує ïx y внутрішній стан. Обраний об'єкт перетворюється на потребу, тобто спрацьовує механізм інтеріоризації.

Інтеріоризація ціннісних орієнтацій у процесі здійснення студентом оцінкової діяльності допомагає йому спроектувати нову діяльність з громадськими еталонами і завданнями саморозвитку і самовиховання, а також реалізувати ï на практиці. Нові об'єкти стають новою потребою - відбувається екстеріоризація.

Надзвичайно важливим механізмом у процесі розвитку ціннісних орієнтацій виступає механізм ідентифікації. Ідентифікація - це процес і результат самоутотожнення 3 іншою мюдиною, групою, образом або символом на підставі устаменого емоційного зв'язку, а також включення іх до свого внутрішнього світу $\mathrm{i}$ прийняття їх як вмасних норм, цінностей і зразків. Це спосіб розуміння іншого через усвідомлене чи несвідоме уподібнення його характеристикам. У процесі ідентифікації з іншими, мюдина просувається від простої імітації до присвоєння і усвідомлення поведінки, якостей, навичок, цінностей та ін., що спочатку йому не належало. 
ДАя майбутнього педагога дошкільної освіти самосвідомість виступає тим внутрішнім механізмом, завдяки якому він здатний не тільки свідомо сприймати ціннісні орієнтації, але і самостійно, усвідоммюючи свої цілі, потреби, мотиви, визначати міру i характер власної активності, спрямованої на їх осмислення i прийняття. Опановуючи професійними ціннісними орієнтаціями, студент суб'єктивує ї. Суб'єктивне сприйняття і присвоєння залежить від стану самосвідомості майбутнього педагога, оскільки факт встановлення цінності того чи іншого педагогічного явища, процесу, а також власних дій. відбувається у процесі аналізу та його оцінки самою особистістю.

Професійна самосвідомість студента спрямована на аналіз і оцінку як вмасної системи цінностей, так i сприйняття професійних ціннісних орієнтацій. Вона покликана визначити межі та перспективи особистісного сенсу, тобто внутрішньо мотивованого індивідуального значення тієї чи іншої педагогічної цінності.

Інакше кажучи, професійна самосвідомість дозволяє самовизначитися по відношенню до пропонованих і особистісних цінностей - вибудувати певну ієрархію професійних мотиваційноціннісних орієнтацій.

у психології термін "рефьексія" вперше почав використовуватися ще у 30-ті і 40-і роки минулого століття. Сьогодні цим поняттям широко оперують філософія, психологія, етика, естетика, педагогіка та інші науки. У науковій мітературі рефлексія розглядається по-різному:

1) форма теоретичної діяльності педагога дошкільної освіти, спрямована на осмислення своїх власних дій і їх законів;

2) вмастивість мислення "обертається на самого себе";

3) усвідомлення суб'єктом того, як він насправді сприймається і оцінюється іншими індивідами;

4) здатність і потреба педагога дошкільної освіти усвідомАювати свої чесноти, зіставцяти свої завдання, дії і досягати результатів у реальних педагогічних ситуаціях $з$ метою контролю, оцінки та вдосконалення педагогічної діяльності;

5) осмислення педагогом дошкільної освіти соціальних реалій в процесі соціамізації на основі життєвого досвіду. Крім того, рефмексія розглядається вченими

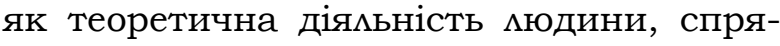
мована на осмислення ним навколишнього світу, усвідомлення себе в цьому світі, своєї діяльності, того, як його сприймають і оцінюють інші.

У наведених вище трактуваннях, на наш погляд, відсутній результативний аспект рефцексії - побудова педагогом дошкільної освіти нової системи ціннісних орієнтацій. Виходячи з цього, ми будемо розуміти під рефмексією: 1) діяльність майбутнього педагога дошкільної освіти, яка повинна спрямовуватись на осмислення ціннісних орієнтацій; 2) усвідомлення себе, своїх духовних, соціальних, особистісних i професійних ціннісних орієнтацій; 3) усвідомлення суб'єктом стороннього сприйняття і сторонніх оцінок, що дозвомяють прийти до нового розуміння "Япрофесійного", скорегувати наявну i вибудувати нову систему ціннісних орієнтацій.

Теоретичний аналіз і практичні спостереження показують, що освітній процес педагогічного вузу спрямований сьогодні переважно на розвиток інтелекту студента, на розширення його теоретичних знань, в той час як ціннісна сфера також потребує розвитку. А духовний світ педагога дошкільної освіти, його цінності, ціннісні орієнтації та мотиви це свого роду вісь свідомості, яка забезпечує стійкість особистості, спадкоємність певного типу поведінки i діяльності.

Вивчення психолого-педагогічної Аітератури дозволило уточнити психомогічний зміст ціннісних орієнтацій, виділити і конкретизувати їх типи.

Ціннісними орієнтаціями педагога дошкільної освіти є спрямованість особистості на створення, зміцнення і поширення цінностей як ідеальних об'єктів особливо значущих духовних, соціальних, особистісних і професійних установок, орієнтованих на дитину, його здоров'я і безпеку, виховання і розвиток, комфортне перебування і стійку соціалізацію в освітньому просторі дошкільного закладу.

Висновки. Відповідно, розвиток ціннісних орієнтацій $є$ складним, поетапним процесом перетворення цінностей шляхом набування професійної значущості та особистісного сенсу під впливом психологічних умов, об'єктивно сприяючи підвищенню ефективності процесу їх вдосконалення на етапі навчання у ЗВО. 
Актуалізація, доповнення та уточнення раніше набутих знань про цінності, ціннісні орієнтації педагога дошкільної освіти, сприяння процесу їх осмислення i сприйняття студентом; відпрацювання елементарних навичок i вмінь психодіагностики, прийомів психокорекції, необхідних у професійній діяльності, підвищення рівня загальної психологічної культури, психологопедагогічної компетентності учасників, розвиток їх здатності ефективно взаємодіяти 3 оточуючими; розвиток творчого, комунікативного, мотиваційного потенціалу особистості кожного студента; вдосконалення ціннісної сфрери, активної соціальної позиції учасників і розвиток їх здатності виробляти значущі зміни у власному житті і житті дітей дошкільного віку - усе це завдання навчально-виховного процесу сучасних закладів вищої педагогічної освіти.

\section{Список бібціографічних посицань}

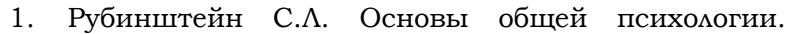
Санкт-Петербург: Питер, 2000. 720 с.

2. Фромм Э. Иметь или быть. Москва: Наука, 1990. $317 \mathrm{c}$.
3. Маслоу А. Самоактуализация цичности и образование [пер. с ангм. и общ. ред. Г.А. Бамла]. КиевДонецк : Институт психологии АПН Украины, 1994. 52 c.

4. Узнадзе Д.Н. Общая психомогия / Пер. с грузинского Е. Ш. Чомахидзе; под ред. И. В. Имедадзе. Москва: Смысл; Санкт-Петербург: Питер, 2004. $413 \mathrm{c.}$

5. Здравомыслов А.Г. Потребности. Интересы. Ценности Москва: Политиздат, 1986. 223 с.

6. Ядов В.А. Саморегуляция и прогнозирование социального поведения мичности диспозиционная концепция / ред. В.А. Ядов ; [2-е расширенное изд]. Москва: ЦСПиМ, 2013. 376 с.

\section{References}

1. Rubinstein, S.L. (2000). Basics of general psychology. St. Petersburg: Peter. 720 p.

2. Fromm, E. (1990). Have or be. Moscow: Science. 317 p.

3. Maslow, A. (1994). Self-actualization of the individual and education. In G.A.Balla (Transl. and Ed.). Kiev-Donetsk: Institute of Psychology of the Academy of Pedagogical Sciences of Ukraine. 52 p.

4. Uznadze, D.N. (2004). General psychology. In I.V. Imedadze (Ed.), E.Sh. Chomakhidze (Transl. from Georgian). Moscow: Meaning; St. Petersburg: Peter. $413 \mathrm{p}$.

5. Zdravomyslov, A.G. (1986). Needs. Interests. Values. Moscow: Politizdat. 223 p.

6. Yadov, V.A. (2013). Self-regulation and prediction of a person's social behavior: dispositional concept. 2nd edition, extended. In V.A. Poisons (Ed.).Moscow: TsSPiM. 376 p.

\section{LYSENKO Oleksandra, \\ Ph.D in Philology, Associate Professor of Theory and Methodology of Preschool and Special Education Department, Pedagogical Faculty, Vasyl Stefanyk Precarpathian National University e-mail: lysenkowa@gmail.com \\ PSYCHOLOGICAL AND PEDAGOGICAL CONTENT OF VALUABLE ORIENTATIONS OF THE MODERN TEACHER OF PRESCHOOL EDUCATION}

\begin{abstract}
Introduction. The article analyzes the concepts of "pedagogical content", "identity", "modern teacher". Considered work of psychologists, philosophers, sociologists and educators is definite problem. It is proved that national identities - a necessary condition for maintaining the nation code. The study of problems with the growth of the national factor is relevant both in theoretical and practical aspects.

Purpose. The article analyzes the value orientations of the personality in the psychological literature. It was emphasized that the greatest significance of the notion of value orientations was obtained only in humanistic and existential psychology. The emphasis is placed on the fact that the source of personal values is the moral of society. It is proved that the main prerequisite for psychological readiness of a student for pedagogical activity in the system of preschool education is the formation and development of his value orientations.

Methods of analysis, comparison, abstraction are used in article.

The study of psychological and pedagogical literature allowed to clarify the psychological content of value orientations, to highlight and specify their types. Valuable orientations of the teacher of preschool education are the orientation of the individual towards the creation, strengthening and dissemination of values as the ideal objects of especially important spiritual, social, personal and professional settings, aimed at the child, his health and safety, upbringing and development, comfortable stay and a stable socialization in the educational space of a preschool institution.
\end{abstract}

Conclusions: Accordingly, the development of value orientations is a complicated, phased process of transformation of values through the acquisition of professional significance and personal meaning under the influence of psychological conditions, objectively contributing to improving the efficiency of the process of improving them at the stage of studying.

Updating, updating and refinement of previously acquired knowledge about values, value orientations of the teacher of preschool education, promotion of the process of their comprehension and perception by the student; working out of elementary skills and skills of psychodiagnostics, techniques of psycho-correction, necessary in professional activity, raising the level of general psychological culture, psychological and pedagogical competence of participants, developing their ability to effectively interact with others; development of creative, communicative, and motivational potential of the individual of each student; the improvement of the value sphere, the active social position of the participants and the development of their ability to make meaningful changes in their own lives and lives of preschool children - all this is the task of the educational and educational process of modern institutions of higher pedagogical education.

Keywords: value; value orientations of the person; preschool institution; future teacher of the institution of preschool education.

Одержано редакиією 14.08.2018 Прийнято до публікаиї 23.08.2018 